\title{
16 Heroes and villains of the American 16 railroads: John Henry, Casey Jones, Railroad Bill and Jesse James
}

This Chapter explores the lives of some of the best known heroes and villains whose exploits on the railroad were celebrated in song. Those featured have more in common than might be immediately thought, they all lived short lives in the late nineteenth-century and in each case their story is tinged with elements of both wrongdoing and heroism, whether factually correct or otherwise. The heroic Casey Jones could be, and indeed was, found guilty of dangerous driving. Strongman John Henry's feat of strength could be seen as a reckless act given that it led to his death. Both Railroad Bill and Jesse James were often hailed as Robin Hood figures, and although Railroad Bill did occasionally donate his loot to the poor, in the case of Jesse James there was no truth in this characterization at all.

\section{John Henry}

Some of the most well-known steel driving songs are about John Henry, a folk hero, strong and powerful, who could work longer than any man and who was renowned for pitting himself against the might of a new-fangled steam drill, consequently hammering himself to death. Although not all elements of this story can be verified, research has shown that as a young man John Henry may have been a steel driver on the tunnels of the Chesapeake \& Ohio Railroad. In his work, Hear My Sad Story, the American historian Richard Polenberg (2015) recounts the true stories that inspired the song John Henry and other characters in American folk songs. 
In February 1870, tracks for the Chesapeake and Ohio Railway were being laid through the Appalachians...the workers reached Big Bend Mountain, which was too high to go over and too large to go around. So a tunnel had to be cut through a mile of solid rock... When finally completed on September 12, 1872, the tunnel was 6,450 feet long, 17 feet high and 13 feet wide. The entire project took more than two and a half years and required nearly a thousand workers, some of whom were prisoners leased by the state to private contractors. Many workers were injured, others lost their lives in accidents and landslides, and still others collapsed because of the backbreaking nature of the labor. One of those who died, most likely in the fall of 1870, was a black man named John Henry. ${ }^{1}$

The work he was doing was hazardous. Thick smoke from the blasts and the candles used to light the tunnel became so thick that visibility was reduced to a few steps. Other dangers included falling rocks, fetid air, and the fragility of the wooden arches that supported the roof. A report in December 1870 observed that "The scene in the scantily lighted tunnel grew to resemble an inferno, men going about naked in the intense heat."

In the early 1920s, the academic Louis Watson Chappell embarked on a folk-lore study of John Henry. He interviewed a few men who had worked alongside John Henry when he was working on the tunnel. Their recollections of him were very similar. All remembered him as being black, six feet tall and well-built, a great gang-leader, worker and singer. Chappell's account however, has been disputed in its details, date and location. A consensus has never been reached. This is best summarised by the American folklorist Richard Dorson when he writes of the different accounts of John Henry. 'He comes from Tennessee most often, but also from East Virginia, Louisiana, and Mobile, Alabama. His hammer weighs nine, ten, twelve, sixteen, twenty and thirty pounds; sometimes he carries a hammer in each hand.'3 Another account that has received some credence comes from an anthropologist, MacEdward Leach, who in 1967 published an essay that sets the origins of John Henry in Jamaica rather than the USA. His account, which stems from the discovery of a song on the back of a map dated around 1894, claims that John Henry died during construction work on the Kingston - Port Antonio railroad.

Ten pound hammer it crushed me pardner

Ten pound hammer it crushed me pardner

Ten pound hammer it crushed me pardner

Somebody dying every day. 
The components of the narrative usually cover John Henry's premonition as a child that steel driving would result in his death, preparation for the contest, the race against the steam hammer, his death and burial and the reaction of John Henry's wife. ${ }^{4}$ Versions of the song are also sung to several different tunes. Here are the lyrics as sung by white American hillbilly singer Fiddlin' John Carson.

\section{John Henry as sung by Fiddlin' John Carson}

John Henry was a very small boy,

Fell on his mammy's knee;

Picked up a hammer and a little piece of steel,

"Lord, a hammer'll be the death of me,

Lord, a hammer'll be the death of me."

John Henry went upon the mountain,

Come down on the side;

The mountain so tall, John Henry was so small,

Lord, he lay down his hammer and he cried,

"Oh, Lord,"

He lay down his hammer and cried.

John Henry was on the right hand,

But that steam drill was on the left;

"Before your steam drill beats me down,

Hammer my fool self to death,

Lord, I'll hammer my fool self to death."

The captain says to John Henry,

"Believe my tunnels fallin' in."

"Captain you don't need to worry,

Just my hammer hawsing in the wind,

Just my hammer hawsing in the wind."

"Look away over yonder, captain.

You can't see like me."

He hollered out in a low, lonesome cry,

This hammer'll be the death of me,

Lord this hammer'll be the death of me."

John Henry told his captain,

"Captain you go to town

Bring John back a twelve-pound hammer,

And he'll whip your steam drill down,

And he'll whip your steam drill down."
For the man that invented that steam drill

Thought he was mighty fine,

John Henry sunk a foteen foot,

The steam drill only made nine,

The steam drill only made nine.

John Henry told his shaker,

"Shaker, you better pray,

For if I miss this six-foot steel,

Tomorrow'll be your buryin' day.

An' tomorrow'll be your buryin' day."

John Henry told his lovin' little woman,

"Sick and I want to go to bed;

Fix me a place to lay down, child

Got a rollin' in my head,

Got a rollin' in my head."

John Henry had a lovely little woman,

Called her Polly Ann;

John Henry got sick and he had to go home

But Polly broke steel like a man,

Polly broke steel like a man.

John Henry had another little woman,

The dress she wore was blue;

She went down the track and she never looked back,

"John Henry, I've been true to you." 
In 1924 Fiddlin' John Carson (1868-1949) was the first to record 'John Henry'. This was followed by a steady stream of recordings - nearly 50 by 1948 . Since then hundreds more recordings have followed, notably by blues singers Leadbelly and Mississippi John Hurt, country singer Johnny Cash, American folk singers Woody Guthrie and Pete Seeger, rock musician Bruce Springsteen, and British skiffle singer Lonnie Donegan. The appeal of John Henry stretches beyond the field of popular music. In 1940 a musical about John Henry appeared on Broadway with Paul Robeson in the lead role, however, after poor reviews it closed after only a few days. In 2009 the American composer Julia Wolfe (b. 1958) drew on different versions of the story in her piece Steel hammer and over 50 years earlier another American composer, Aaron Copland (19001990) composed John Henry a short work for school orchestra simulating the sounds of a train and John Henry's steel hammer.

\section{Casey Jones}

Come all you rounders ${ }^{5}$, if you want to hear

The story told of a brave engineer

Casey Jones was the rounder's name

A high right-wheeler of mighty fame.

Train speeds had increased to at least 60 miles per hour in the 1890s and they became more difficult to control. Between 1895 and 1905, nearly 80,000 people died in railroad accidents, roughly a third of them were railroad employees. ${ }^{6}$ One of those was Jonathan Luther Jones, nicknamed 'Casey', who died on April 30, 1900, when he tried to prevent his speeding train from crashing into another train. He saved all the passengers. His friend, an African American engine wiper named Wallace Saunders, wrote the first version of 'The ballad of Casey Jones', a tribute to the engineer. Several versions were sung over the years by countless people with hundreds of recordings being made. Casey Jones became a legend.

John Luther Jones was born on March 14, 1863, in Missouri. When his family moved to Cayce, Kentucky, the name of this town later served as his nickname, it was used to distinguish him from the many other Welsh-American Jones's. At the age of 15, he moved to Columbus, Kentucky, where he found work on the Mobile \& Ohio Railroad, as a labourer then a telegrapher. From there he moved up to flagman and then brakeman, moving again, this time to 
Jackson, Tennessee. Here he met Joanne Brady, known as Janie, who became his wife. In 1887 he was promoted to engineer, working for the Illinois Central Railroad. Each engineer was allowed to install his own train whistle and Casey Jones was well-known for the sound of his distinctive six-chime train whistle. In the words of the song

The switchman knew by the engine's moans That the man at the throttle was Casey Jones.

In January 1900 Jones took over the controls of the Cannonball Express, a fast passenger train running from Chicago to New Orleans. On Sunday April 29, 1900, Casey Jones and his fireman Sim Webb were due to take the Cannonball Express on its 188-mile run south to Canton, but the train arrived 95 minutes behind schedule and they had to set off early the following morning. Jones had a reputation as a 'fast roller' and they were determined to make up for lost time, and indeed they did regardless of the darkness, the fog and the rain. ${ }^{7}$ They were almost on schedule and close to their final destination, but because of unusual circumstances the caboose $e^{8}$ of a freight train was in the way on the mainline. As Jones caught sight of the lights of the caboose, he told Webb to jump as he tried to apply the brakes. The following is how the fatal crash was reported on May 11900 on the front page of the Memphis Commercial Appeal.

\section{DEAD UNDER HIS CAR THE SAD END OF THE ENGINEER CASEY JONES}

\section{ILLINOIS CENTRAL WRECK}

Southbound Passenger Train No. 1 Crashes into the Rear of a Freight Details of the accident.

Jackson, Miss. April 30 - (Special) - A disastrous collision occurred about 4 oclock this morning on the Illinois Central Railroad at Vaughan, a station eleven miles north of Canton. The Engineer, Casey Jones, was instantly killed and Express Messenger Miller was hurt internally, but not seriously.

The south-bound passenger train was running under a full head of steam when it crashed into the rear end of a caboose and three freight cars which were standing on the main track... The caboose and two of the cars were smashed to pieces, the engine left the rails and plowed into an embankment, where it overturned and was completely wrecked, the baggage and mail coaches also 
being thrown from the track and badly damaged. The engineer was killed outright by the concussion. His body was found lying under the cab with his skull crushed and the right arm pulled from the socket. The fireman jumped just in time to save his life. The express messenger was thrown against the side of the car, but his condition is not considered dangerous.

The other employees and all of the passengers were more or less jolted by the shock, some of them receiving bruises and slight wounds, none of which, however, were serious.

Every effort was made to stop the speeding train, but without success. Two flagmen were sent down the track with danger signals and torpedoes were placed on the rails as a warning, but the engineer did not seem to take any notice of the signals nor to realise the situation until a short distance of the caboose, when he made a violent attempt to put on the airbrakes, but the distance was too short to avoid a crash. The freight boxes were loaded with bundled hay and the scattered coal from the engine soon set fire to the debris, and it was feared at one time that the whole mass of wreckage would be destroyed, but the fire was eventually extinguished without doing very great damage...

This is essentially what happened. ${ }^{10}$ Although rather than dying of a crushed skull, Sim Webb later recalled that 'they found Casey with one hand clutching the throttle and the other the air-brake control' and that Jones died because either a metal bolt, or a piece of splintered wood, pierced his throat. Although the Memphis Commercial Appeal report concluded with the words that 'Engineer Jones ...was highly esteemed as one of the road's safest and most capable engineers, ${ }^{11}$ this was not the view of the officials of the Illinois Central Railroad company who had found his safety record wanting in previous years and had suspended him no less than nine times in violation of rules. The company investigation following the fatal crash came to the unequivocal conclusion that "Engineer Jones was solely responsible for the accident as consequence of not having properly responded to flag signals. ${ }^{12}$ His body was sent back to Jackson, Tennessee and a funeral mass was held the next day at the church where he had married Janie Brady 14 years earlier. Railroad men came from miles around to attend the funeral and pay their last respects. In the aftermath, however, Jones became the legend who had unselfishly given his life so that everyone on his train would live.

When Jones's friend Wallace Saunders composed the earliest ballad about Casey Jones, he used a popular tune, 'Jimmie Jones' but he did not copyright the lyrics. One verse tells of Jones' resolve to reach his destination on time. 
Fireman say, "You running (too) fast, You ran the last three lights we passed" Casey say, "We'll make it through, She's steamin' better than I ever knew"

In 1901 two vaudeville performers, T. Lawrence Seibert and Eddie Newton, were the first to copyright the song when they published their version which they called 'Casey Jones, the Brave Engineer'. One of the earliest recordings of this version was by Billy Murray in 1911. This included a verse which suggested that Mrs. Jones had found someone to replace Casey.

Miss Casey Jones setting upon the bedside

When she received the message that her Casey had died

Says, go to bed chillun' and ahush your crying

For youve got another poppy on the Salt Lake Line.

Not surprisingly she was offended and spent many years disclaiming the idea that she was having an affair. ${ }^{13}$ Murray's recording was so popular that within 20 years of Jones's death, many versions of the song had been recorded, millions were sold, and the sheet music was widely available. Making the most of the song's popularity, a parody, 'Casey Jones—the Union Scab', appeared in 1911. The words were written by Joe Hill, an organizer of the radical union Industrial Workers of the World at the start of a walkout of 40,000 railway workers. The lyrics told of a railroad worker who refused to support a strike, then died and went to heaven to be told by St. Peter that he could get a job as a scab. It was largely forgotten until Pete Seeger recorded it in 1941 on an album called Talking Union. Carl Sandburg included the song in his book of American folk songs, and described it as the 'greatest ballad ever written. ${ }^{14}$ The first blues singer to record it was Mississippi John Hurt but the recording was never issued. Instead it was the black singer Walter "Furry" Lewis's who introduced the song to blues audiences when he recorded it in 1928 with the title 'Kassie Jones', deliberately misspelled to avoid copyright infringement. The lyrics include the well-known chorus

On the road again,

I'm a natural born eas'man, on the road again.

There are now hundreds of recordings of the song and many variations of it including another take from bluesman Jesse James, 'Southern Casey Jones' (1936) and a much later Grateful Dead song 'Casey Jones' (1970) written by Jerry Garcia (see pages 269-70). ${ }^{15}$ 


\section{Railroad Bill}

Railroad Bill ought to be killed

Never worked and he never will

Now I'm gonna ride my Railroad Bill

Morris Slater (the real name of Railroad Bill) was born a slave in North Carolina. In the 1890s he became notorious as a train robber, mostly in southern Alabama on the Louisville \& Nashville Railroad (L\&N), a thriving company with more than 2,614 miles of track, hundreds of locomotives and passenger cars, and thousands of freight cars. ${ }^{16}$ Slater's first crime took place in 1896 when he shot at the deputy sheriff Allen W Brewton in Bluff Springs, Florida. Brewton had told Slater that he needed to buy a licence for his Winchester rifle or to give it up. Brewton fired at him and missed, Slater fired back and then disappeared into the swamp to become a wanted man. He remained at large for more than three years, moving around the area, riding boxcars, robbing trains and freight stations, and shooting it out with the law. Sometimes he kept the stolen goods and sometimes he gave them away or sold them off cheap to the local poor. To many blacks in Alabama he became a folk hero, but at the same time he became the object of a manhunt. One of those out for Slater's blood was Sheriff Edward McMillan. In 1895 he received a tip off and located Slater in a house near Bluff Springs. The shooting that followed resulted in McMillan's death and again Slater slipped out of sight. Some versions of the song include the following verses:

Railroad Bill made a mighty dash

Shot McMillan by a lightning flash

Talkin' bout that Negro, Railroad Bill.

Railroad Bill, goin' down the hill

Lightin' cigars with a five-dollar bill

And its ride, ride, ride.

A reward of $\$ 1,250$ was offered for information leading to Slater's arrest, $\$ 350$ of it was pledged by the L\&N railroad, which also threw in a free railroad pass for life. Consequently the size of the search parties increased, 'harassing, arresting, or beating blacks, blameless though they may have been, who were suspected of shielding Slater. ${ }^{17}$ Slater remained at large committing further train robberies, often breaking into a railroad car, throwing the valuables onto 
the track with the train still in motion and then returning to collect the loot. Some years later a report was written by J B Harlan who had been working for the L\&N police and had been assigned to capture Slater. Naturally he was entirely without sympathy for Slater, but he made it clear that the view of the local black population was different.

it was generally believed and talked by the negroes in that section of the country that "Railroad Bill" was superior being, possessed of super-human powers and, having been shot at so many times by different raiding parties, that he could not be killed with an ordinary leaden bullet; some of them claiming that the only bullet that would kill him was a solid silver missile. ${ }^{18}$

Eventually the law caught up with Slater in March 1896 at a general store in Atmore, Alabama, where he sat armed with a Winchester rifle and two loaded pistols and eating stolen cheese and crackers. Accounts of what exactly happened next differ, but the shootout resulted in Slater's death.

Railroad Bill lyin' on de grocery floor

Got shot two times an' two times more

No more lookin' fer Railroad Bill.

His body was embalmed and then exhibited far and wide to large crowds who paid an admission fee to see it. Not long after his death, songs started to be written about Railroad Bill. Verses were collected as early 1909 and were published a couple of years later by E. C. Perrow and by Howard W. Odum. Some versions have few direct references to Slater's train robbing history, rather they refer to him as an idle womaniser. The version included in Carl Sandburg's American Songbag, for example, includes the following verses. ${ }^{19}$

Railroad Bill, Railroad Bill,

He never work and never will;

Well, it's bad Railroad Bill.

Railroad Bill had no wife,

Always looking for somebody's wife;

Then it's ride, ride, ride.

Railroad Bill, might bad man

Shot the lantern out the brakeman's hand

Bad Railroad Bill. 
The first recordings appeared in 1924 by Roba and Bob Stanley, as well as Gid Tanner, Riley Puckett, and the Skillet Lickers. 'Railroad Bill' songs became more widespread during the urban folk revival and its popularity continued with recordings by Joan Baez, Lonnie Donegan, Bob Dylan, Ramblin' Jack Elliott, and Sonny Terry and Brownie McGhee.

\section{Jesse James}

It was on a Wednesday night, the moon was shining bright They robbed the Glendale Train.

And people they did say, for many miles away

"Twas those outlaws Frank and Jesse James.

\section{Chorus}

Jesse had a wife to mourn all her life,

The children they are brave,

'Twas a dirty little coward shot Mister Howard

And laid Jesse James in his grave.

It was Robert Ford, the dirty little coward.

I wonder how he does feels,

For he ate of Jesse's bread and he slept in Jesse's bed,

Then laid Jesse James in his grave.

It was with his brother Frank he robbed the Gallatin Bank,

And he carried the money from the town.

It was in this very place they had a little race,

For they shot Captain Sheets to the ground.

They went to the crossing not very far from there,

And there they did the same.

And the agent on his knees, he delivered up the keys

To the outlaws Frank and Jesse James.

It was on a Saturday night, Jesse was at home

Talking to his family brave,

When the thief and the coward, little Robert Ford,

Laid Jesse James in his grave.

How people held their breath when they heard of Jesse's death,

And wondered how he ever came to die.

"Twas one of his gang, dirty Robert Ford

That shot Jesse James on the sly. ${ }^{20}$ 
Jesse James was a murderer and an outlaw, arguably the most famous outlaw in American history. He was born in 1847 in Kearney, Missouri, the son of a Baptist preacher. His older brother Frank fought on the side of the South in the American Civil War and was a member of the notorious Quantrill's Raiders who in Lawrence, Kansas, in August 1863 engaged in an orgy of looting and murder. The following year Jesse James, aged 16 , joined his brother in the gang. When the Quantrill Raiders broke up in 1865 the brothers formed the JamesYounger gang with other ex-guerrillas and turned to robbing banks - seven in the next three years, the first being the Clay County Savings Association in Missouri. As they made their getaway, one of the robbers shot and killed a bystander. In another bank raid in Gallatin, Missouri, James mistakenly thought that one of the bank clerks was his nemesis Lieutenant Colonel Samuel P. Cox and shot him through the heart.

After laying low for over a year they committed a further 12 robberies in just over three years. In 1873 they turned their attention to railroads. The Chicago, Rock Island and Pacific Railroad was their first target. The gang derailed the train and broke into the safe. The engineer died in the crash and some passengers were injured. In July 1876 the James gang stopped the Missouri Pacific Railroad train and made off with thousands of dollars. Their next target was the Chicago \& Alton Railroad at Glendale, Missouri. Between 1880 and 1881 there were four more hold-ups but, unknown to James, the gang had been infiltrated by two brothers, Robert and Charles Ford, who had been offered a pardon and a reward for the murder of Jesse James by the governor of Missouri, Thomas T. Crittenden. The Ford brothers were related to the James family and had been invited to stay with them. On the morning of April 3, 1882 Jesse James climbed on a chair to dust a picture and was shot in the back by Robert Ford, he died instantly. He was buried at his mother's home, and his grave became a shrine with countless viewers paying to see it.

James had already been built into a hero during his lifetime, a latter day Robin Hood, but there is no evidence to support any such good deeds. In reality he was a train robber who had little or no sympathy for his victims and killed several people along the way. James himself helped to create this sympathetic image, writing to newspapers attempting to justify his motives and covering a range of excuses: sometimes portraying himself as robbing the rich to give to the poor; sometimes saying that he was acting in self-defence, ${ }^{21}$ and even claiming that he had to rob in order to pay his heavy taxes. ${ }^{22}$ So why was the 
general population so sympathetic to James? Norm Cohen argues that there was a general antipathy towards the railroads going back to the 1870s: farmers had felt cheated in their land deals; some had lost their savings in railroad stocks and bonds; many felt that the freight rates were unfair and that they had to pay over the odds to transport their products to the market. There was a similar antipathy to the banks: farmers had had to borrow large sums to buy new machinery and when agricultural prices fell some were unable to pay their mortgages. Consequently there was little sympathy for what was perceived as the wealthy victims. All this helped to make the holdups a popular crime. ${ }^{23}$

There has been much debate about the authorship of the song. For a full discussion see Norm Cohen's Long steel rail: the railroad in American folksong. ${ }^{24}$ The earliest version of a song about Jesse James was published in 1887 in a small book of songs, and a few years later the verses appeared on a New York City broadside. In 1910 the song was published in John A. Lomax's Cowboy Songs and Other Frontier Ballads. The Lomax version portrays Jesse James as a friend to the poor, who 'never would see a man suffer pain.'

The first recording of 'Jesse James' was made by Bentley Ball in 1919. Another early recording was made by Riley Puckett in 1925, included the sympathetic line 'Dear old Jesse, poor old Jesse' and a sign of repentance, 'He fell down upon his knees and he handed up the keys / To the bank that he had robbed the day before.' Harry McClintock's 1928 recording was again on the side of the outlaw and included the lines 'he took from the rich and he gave it to the poor'. In 1939 Woody Guthrie followed the same line claiming that the brothers 'never was outlaws at heart'; 'the railroad bullies come to chase them off their land'. Many recordings have followed notably by Pete Seeger, The Pogues, Van Morrison and Bruce Springsteen. 


\section{Endnotes}

1 Richard Polenberg. Hear My Sad Story: The True Tales That Inspired "Stagolee," "John Henry," and Other Traditional American Folk Songs. (New York: Cornell University Press, 2015): 150.

2 Cited in Polenberg, Hear My Sad Story, 149.

3 Richard M Dorson. "The Career of "John Henry". Western Folklore, July, 1965, Vol. 24, No. 3. (Long Beach California: Western States Folklore Society): 162.

4 Norm Cohen. Long steel rail: the railroad in American folksong. (Urbana: University of Illinois Press, 2000): 72.

5 'Rounders' is an American term referring to itinerant railroad men.

6 Polenberg, Hear My Sad Story, 163.

7 Cohen, Long steel rail, 136-7.

8 A caboose is a manned North American railroad car coupled at the end of a freight train.

9 May 1 1900, Memphis Commercial Appeal.

10 Cohen, Long steel rail, 137.

11 Memphis Commercial Appeal, May 1, 1900.

12 Polenberg, Hear My Sad Story, 166.

13 Cohen, Long steel rail, 144.

14 Carl Sandburg. The American Songbag. (New York: Harcourt Brace Jovanovich, 1927).

15 For a full discussion of the many versions and recordings of the song see Norm Cohen pp 132-157.

16 Polenberg, Hear My Sad Story, 130-131.

17 Polenberg, Hear My Sad Story, 133.

18 Cited in Cohen, Long steel rail, 124.

19 Sandburg, The American Songbag, 384.

20 Sandburg, The American Songbag, 420.

21 Cohen, Long steel rail, 102.

22 Polenberg, Hear My Sad Story, 115.

23 Cohen, Long steel rail, 102.

24 Cohen, Long steel rail, 103- 107. 
10.5920/railways. 16 